\title{
STYLISTIC ANALYSIS “THE SNAKE"- BY D.H. LAWRENCE
}

\author{
Instructor Munna Ibrahim Ahmed \\ University of Baghdad, College of Education, Ibn Rushd, Department of \\ English Language \\ muunatti@gmail.com
}

Received: $26 / 1 / 2020$

Accepted: 31/3/2020

This work is licensed under a Creative Commons Attribution 4.0 International License

\begin{abstract}
Stylistic analysis implies analyzing a poem from the linguistic as well as critical point of view. While the former leads to a better understanding of the devices used and the construction of the poem, the latter enables one to look at the poem from a critical angle. Together, one gets a complete and comprehensive picture of the poem. In stylistics, it is possible to look at a poem from the point of view of graphology, morphology, phonology and lexico-syntactic level. In this paper, the poem "the Snake' by D. H. Lawrence has been analysed stylistically. It helps the reader to notice the unique features of the poem that may be otherwise missed and leads to a better understanding of the poem.
\end{abstract}

Key words: stylistic analysis, morphology, phonology, lexis, graphology, syntax, literary criticism 


\section{تحليل أسلوبي لقصيدة دي-ايج لورنس (الأفعى) المدرس منى إبراهيم أحمد}

\section{جامعة بغداد / كلية التربية (بن رشد للعلوم الإنسانية / قسم اللغة الاكليزية}

المستخلص:

يتضمن التحليل الأسلوبي تحليل قصيدة دي أيج لورنس من منطلق لغوي ومن وجهة نظر نقدية؛ لأن التحليل اللغوي للقصبدة يفضي إلى فهم أفضل للوسائل المستعملة في القصيدة، فضلا عن بناء القصيدة.. أما وجهة النظر النقدية؛ فتمكن الناقد من النظر الى القصيدة من زاوية نقدية .... فضلا عن ذلك يتمكن الناقد من التوصل الى صورة شاملة وكاملة للقصيدة .... فمن الممكن في علم دراسة الأساليب أن ينظر الناقد الى القصيدة من منطلق علم الأستدلال الخطي (علم الكتابة) وعلم الصرف، ونه و علم وظائف الأصوات، و علم الأساليب القاموسي •

تهدف هذه الدراسة الى تحليل قصيدة الشاعر دي أيج لورنس "الأفعى" حيث تسعى الدراسة الحالية إلى مساعدة القارئ لملاحظة الخواص الفريدة من هذه القصيدة التي يمكن أن تكون مفقودة بطريقة أخرى في قصائد أخرى، و التي تؤدي الى فهم شامل للقصيدة برمتها. الكلمات المفتاحية: تحليل أسلوبي ، علم الصرف ، علم وظائف الأصوات ، علم الكتابة و النقد الأدبي 


\subsection{Introduction}

\section{SECTION 1}

'Stylistics' is a word derived from style. It is a discipline which studies different styles. According to Widdowson, Stylistics is different from literary criticism on the one hand and linguistics on the other because it is essentially a means of linking the two. Stylistics involves both literary criticism and linguistics. Stylistics was initially born of a reaction to the subjectivity and impression of literary studies, and in short, attempted to put criticism on a scientific basis. ( Fish, 1980; Short, 1982). In other words, literary criticism was thought of as imprecise and subjective and so stylistics was born in order to objectify claims made about the way in which literary texts carry meaning. Widdowson, (1975) defines stylistics as 'the study of literary discourse from a linguistic orientation.'

Stylistic analysis requires a different set of skills. Analyzing a text stylistically is unlike doing 'literary' analysis as it needs to be much more objective and rooted in fact. With stylistics, we can explain how the words of a text create the feelings and responses that we get when we read them. Linguistics is the study of language in a scientific way. Poets make special use of language. They use it symbolically, metaphorically and creatively. The application of linguistics to literature is called stylistics. Stylistics includes the way a poet arranges the lines in a poem, uses figures of speech to convey meaning and the way he structures the sentences.

By analyzing the poem 'The Snake' by D. H. Lawrence, we shall see how such an analysis may be structured, how to relate linguistic elements to meaning and how to provide an objective account of the text.

\subsection{Significance of the problem}

Carrying out critical analysis or appreciation of literary texts requires thorough knowledge of the language, its systems, various aspects of language and literature and socio-political background of the times when the piece of literature was written. Some knowledge about the writer's / poet's background is also sometimes necessary to delve deep into literature and open out layers of underlying meaning. In case of poetry, stylistic analysis of a poem helps to understand the nuances and bring out the beauty of a poem by taking into consideration all aspects. Poetry as a genre has certain characteristics that are different from those of drama or fiction. hence, stylistic analysis of a poem helps to reveal its deep meaning by focusing on each feature of poetry singly and finally looking at the combined effect of all features.

\subsection{Theoretical background}

\section{SECTION 2}

Stylistics: Stylistics is a branch of linguistics. It is the application of linguistic theory to literary texts. Every literary text contains certain formal features. A 
critical reader identifies the features. Stylistics goes beyond locating the features. Katy Wales, in 'A Dictionary of Stylistics' states that " "most stylistics is not simply to describe the formal features of texts for their own sake, but in order to show their functional significance for the interpretation of the text; or in order to relate literary effects to linguistic 'causes' where these are felt to be relevant."

Elements of style: Literature has various forms and hence, a number of elements of style. However, only the elements of style that refer to poetry are discussed here.

Form: Sonnet, elegy, lyric, blank verse are different forms of poetry. The poet chooses a form most suitable for the topic.

Imagery: Creation of images through words is an important element of poetry. These images often convey hidden meaning and need to be interpreted correctly by the reader for understanding the message. Vivid imagery is rich with meaning.

Symbolism: The poet may use symbols to convey meaning indirectly. Original symbols enrich poems and literature.

Mood: Poets may create a mood by using language in a particular way and choosing apt diction.

Irony: The poet may use an ironical tone if he intends to do so.

Metaphor: This adds value and helps better understanding by using comparisons. Poets come out with genuine, striking and original metaphors. Metaphors are related to the meaning of the poem. Metaphor is just one figure of speech. There are several figures of speech like simile, oxymoron, personification, juxtaposition and so on.

Rhyme / rhythm: Poems give pleasure when read aloud. Rhyme and rhythm give a musical quality to poems.

Repetition/alliteration/ assonance: Like rhyme and rhythm, these elements are related to sound. Repetition of words or phrases add emphasis to what the poet wants to say while repetition of sounds create special effects while reading the poem aloud.

Structure: A poem is structured in various ways. A poet can choose a defined structure like a sonnet with 14 lines. A poem may be one whole unit or may be divided into stanzas of differing lengths. There may or may not be regularity in the stanzas. The length of lines may also vary for special purposes.

While doing stylistic analysis of a poem, all the elements are taken into consideration.

\subsection{Review of literature}

According to Peter Barry (1995), the study of rhetoric has been a part of human communication since ancient times. Even the Greek philosopher Aristotle gave importance to rhetoric. 
Stylistic analysis is effective as a course added in EFL program as per an experiment conducted by Akyel (1995). The aim was to find out how it helped to design language activities in an EFL classroom. 24 native Turkish students participated in the experiment and concluded that stylistic analysis of poems enabled them to prepare their own language activities for use in the classroom. Eva María Gómez-Jiménez(2017) claimed in her article that while most studies in stylistic analysis deal with grammar, lexis and morphology, there are very few studies that look at the graphological aspect and very few that consider punctuation. She studied in detail a corpus of 157 experimental poems by E. E. Cummings. She concluded on the basis of the poems that they reveal three unconventional devices in the use of punctuation marks, namely, insertion, omission and substitution. These help the poet to achieve various purposes like "emphasize certain elements within the poem, shift the tempo of the lines, create chaotic scenes, produce iconic effects, schematize any unit within the poem, omit letters and words, signal heteroglossia, indicate imperative voice, articulate the poem into different layers, create plays on words, and reproduce features of spoken language."

Leech (1969) describes style as the way in which something is spoken, written or performed. According to him, style reflects upon the personality of an individual and his thoughts. Short and Candlin (1989, p 183) look at stylistics as a linguistic approach to literary texts which embodies the element of philosophy. Literary styles are the result of devices like rhetorical terms, syntactic devices.

Carter (1996) is of the opinion that stylistic is useful for teaching literature. It "helps to helps to foster interpretative skills and to encourage reading between the lines". It shows a direction for the study of texts. It is a methodological and conscious study of poems.

\section{SECTION 3}

\subsection{Procedure}

The researcher has applied the relevant elements of stylistic analysis to the poem. The entire poem is analyzed from beginning to end. Examples from the text are quoted to support the analysis. A detailed analysis of the whole poem is followed by a conclusion. The researcher has also given some recommendations and suggestions for further research.

\subsection{Population and sample}

Stylistic analysis can be carried out on all kinds of poems from different ages. The poem selected for this study is 'The Snake' by D. H. Lawrence.

\subsection{Tools for analysis}


The poem will be analyzed on the basis of graphology, phonology, and lexicosyntactic and semantic devices.

\subsection{Analysis of the poem}

\section{SECTION 4}

'The Snake' by D.H. Lawrence is a narrative poem that has a very interesting message. The narrator goes to fill his pitcher at the water-trough but finds a snake drinking there so he has to wait. He gives a detailed description of the snake and its movements, as he watches it in fascination. Then he remembers what he has learnt; he remembers that the golden snakes in Sicily are poisonous so he ought to kill it. After drinking its fill, the snake slides back into its hole from which it had emerged. When its back is turned, the narrator picks up a log and hits it and watches it disappearing into the hole hastily. Then he regrets his action. He admits to himself that he should not have behaved in this way and feels guilty and ashamed. The poem is about moral consciousness. Was it right to kill the snake or wrong? We are often confronted with such issues and we generally tend to conform to norms. The poem deals in a unique way with the moral consciousness of society. We are often taught to get rid of things that are different and dangerous (although they do not harm us). We all have a 'snake' in our sub-conscious and more than likely, we have done all we can to kill it. A poem can be analyzed stylistically at various levels. We shall first consider the level of graphology.

GRAPHOLOGY (paragraphing, spacing, font and punctuation marks)

Graphology refers to the way the poet arranges the lines in the poem and divides it into stanzas. The length of the lines may be similar or it may vary. The poet sometimes uses a specific font size. Generally, it is uniform by there are examples of poems in which the font size varies within the poem. The use of punctuation marks to mark off the lines is also included in graphology.

Some stanzas in the poem 'The Snake' contain 2, 3 or 4 lines while some others contain 10 to 12 lines. There is no particular pattern in organizing the stanzas of different lengths. The stanzas which refer to the narrator are short and contain 2 to 4 lines while stanzas that describe the snake and its movements are longer and contain minimum 9 lines.

While the movements of the snake are described in long, rambling lines, the lines that refer to the narrator are comparatively shorter in length. They are quick and rapid.

For example:

The following line describes the snake:

1. And trailed his yellow-brown slackness soft-bellied down, over the edge of the stone trough

The following lines refer to the narrator: 


\section{He must be killed}

2. Ifelt so honored

3. And yet those voices...

Another feature that strikes the vision is that each stanza begins with a short line, they gradually increase in length and again the length of the lines decreases towards the end of each stanza. This corresponds to the body structure of a snake, which is narrow at the mouth, bulges in the centre and again narrows at the end of the tail. Two stanzas end in a single word, resembling the tip of a tail.

There is a full-stop only at the end of each stanza. Most of the lines either end in a comma or there is no punctuation mark because the lines run into the next line. The grammatical units do not correspond with the end and beginning or the lines.

Only two lines end in an exclamation mark, thus achieving a strong foregrounding effect.

1. If you were a man, you would kill him!

2. I thought, how paltry, how vulgar, what a mean act!

Both the above lines refer to something that the narrator does not appreciate from his heart. He is against what the voice of his education dictates and after doing it, he regrets his action. A foregrounding effect is achieved by using the exclamation mark for selected lines which the narrator wants to emphasize.

The line "If you were a man, you would kill him' is also the only line with a different font that is italics. The foregrounding is not only graphical but this is the only line which contains an intense urge to kill the snake. It also happens to be the only line with a conditional clause. It challenges the courage and manlihood of the poet. Ultimately, he gives way and hits the snake in spite of his compassionate attitude because of the different, challenging, urging tone in this line. The line also has a dramatic touch as it is in direct speech. The climax or strong impact and consequently strong foregrounding by use of multiple kinds of devices shows that the poet considers this line as important.

\section{PHONOLOGY}

This includes the use of devices like alliteration, assonance, consonance, onomatopoeia etc, which are related to sound effects.

- In the deep, strange-scented shade of the great dark carob tree, I came down the steps...

This is an example of assonance. The half-rhyme is realized by repeating the same stressed vowel but with different final consonants in a sequence of nearby words. The same stressed vowel occurs in the words strange, shade, great and came.. The final consonant sound in each word is different (/dz/, $/ \mathrm{d} /$, $/ \mathrm{t} /$ and $/ \mathrm{m} /$ respectively). The darkness and depth of the place are emphasized due to this phonological arrangement. It also checks the pace of reading slightly when the line is read aloud, to indicate the slow movement of the snake. 
The same diphthong is repeated in the next line in the word wait. This word literally makes us stop while reading aloud, just as the narrator has to wait for his turn at the water-trough. Use of the same diphthong and the fact that it is stressed, both are responsible for creating this effect.

A parallel effect is achieved by using another diphthong in the words down, brown, stone and throne in the following line:

He reached down from a fissure in the earth-wall in the gloom

And trailed his yellow-brown slackness soft-bellied down, over the edge of the stone trough...

However, the last consonant sound is the same in all the words which are also stressed in these lines. The repetition in the end consonant helps to achieve foregrounding.

...he sipped with his straight mouth

The same diphthongs /ei/ and /au/ in the words straight and mouth follow each other successively in two successive words at the end of the stanza. It gives a kind of sense of completion or rounding off of the assonance used above.

He sipped with his straight mouth,

Softly drank through his straight gums, into his slack long body, silently.

The adverbs and adjectives that refer to the snake and its movements all begin with the sound /s/. It creates a wonderful alliterative effect. Alliteration of /s/ which is a very soft sound is effectively used to create an impact of silence, straightness, calmness, slowness and also resembles the hissing sound that snakes make, and gives an onomatopoeic effect.

Another example of alliteration is observed in the following line:

Being earth-brown, earth-golden, from the burning bowels of the earth.

Along with sound effects the rhythm and meter in certain lines is also worth notice. The following line is an important instance:

You would take a stick and break him now and finish him off!

An attitudinal stress naturally falls on all the action words, indicating the actions that the narrator wants to perform. These action words are stressed and there is a regular time interval between them, creating a rhythmic effect. The meter is anapest.

Foregrounding is achieved by introducing rhythm only in this line which stands apart from the preceding lines. From the point of view of meaning, this line is important because it tells us what the narrator's educated mind tells him to do.

He lifted his head dreamily as one who is drunken

The rhythm in this line creates a swaying effect, just as a person who is drunk would sway. 


\section{MORPHOLOGY}

It refers to the word-formation processes which are subjected to specific conditions and rules of affixation, unusual collocates, archaic words, particular parts of speech, metaphor, simile, oxymoron etc.

One cannot fail to notice the use of compound words in the poem. There are 12 compound words out of which two are nouns and they are commonly used in everyday life. (water-trough and wall- front). The rest of them are adjectives and are coined by the poet.

1. Strange-scented

2. Earth-wall

3. Yellow-brown

4. Soft-bellied

5. Two-forked

6. Earth-brown

7. Earth-golden

8. Earth-lipped

9. Second-comer

10.Snake-easing

The above compound words have helped to boost the compactness of the poem. Hyphenated or unhyphenated or multiple compounds are potentially longer expressions or structures. For example, the poet has described the movement of the snake in the word 'snake-easing his shoulders'. It would have taken 4 to 5 sentences to describe this action but it is aptly understood through the single compound word coined for the purpose. It performs the function of a verb.

The snake does not have shoulders, but the way it lifts itself up from the trough appears as if it raises its shoulders. The ease of the movement is described through this strange phrase. It fits in perfectly, making the point clear that the snake is personified in every sense throughout the poem.

There is no such word as 'adream'. It is coined by the poet.

Throughout the poem, the pronoun 'he' is used to refer to the snake. It is personified. It is also compared to a king, guest and God.

The voice of my education said to me...

In this line, education is personified. By personifying education, the poet has shown how it can influence the thoughts and behavior of human beings. By giving it a status of a human being, its influential power is increased. It dictates our conscience, controls it and kills natural feelings, emotions and urges. Education is constantly present as an impending figure at the back of the narrator's mind, somewhere in his subconscious mind. The conflict between the voice of education and his natural urge is pointed out.

There is a series of similes used throughout the poem. Majority of them are related to the snake. The following simile refers to the narrator, made striking by the strange compound word 'second-comer'. 


\section{Someone was before me at the water-trough}

And I like a second-comer waiting.

At a common water-source, people have to wait for their turn. Here, the narrator emphasizes that it is 'my' water-trough; it belonged to him, implying that he ought to be able to use it whenever he wanted. Yet when he saw the snake, he had to wait. Hence he compares himself to a 'second-comer' who has to wait for his turn. He feels slightly humiliated, a little angry and this feeling of anger and having to wait, for being treated as a second-comer is all reflected in the simile.

He lifted his head from his drinking, as cattle do,

And looked at me vaguely, as drinking cattle do.

While the narrator waited and the snake drank, the snake must have heard or sensed somebody arriving so he looked up from his drinking, as cattle do ( while grazing). This 'looking up' of the snake is compared to the same action of cattle. When the snake saw the narrator waiting patiently with his pitcher, he was assured that there was no danger and continued to drink its fill. Perhaps, it just wanted to confirm that there was no danger, so it looked up, something that cattle also do. Hence the snake, like the cattle, 'vaguely' looked at the poet. Two actions of the snake, lifting its head and looking vaguely at the poet are compared to those of cattle in this simile.

How glad I was he had come like a guest in quiet, to drink at my water-trough In this simile, the snake is compared to a guest, a visit by a guest who makes the host glad. The initial reaction of the narrator was different. He did not like the idea of having to wait at his own water-trough; in this line he confesses that he was glad to have the snake as a guest. The changing attitude of the narrator towards the snake is reflected in the simile.

And lifted his head dreamily as one who has drunken

And flickered his tongue like a forked night on the air, so black...

After drinking to its content, once again the snake lifted its head; this time, the movement of the snake is compared to that of a drunken man. The happiness, satiation and satisfaction of the snake is evident in its movement. When the snake put out its forked tongue to lick its lips, the narrator got a glimpse of it, it was dark black and the poet has compared it with the black night.

And looked around like a God...

After drinking the water, the snake did not seem to be in hurry. It looked around as if with unseeing eyes. The narrator has compared him to God. Thus, the changing status of the snake from first-comer to guest to God! The snake is the same; the narrator thinks of it in a different way every time!

But suddenly that part of him that was left behind convulsed in undignified haste,

Writhed like lightning and was gone. 
The snake slowly slithered from the water-trough into its black hole in the wall. As soon as its back was turned, the narrator picked up a log and threw it at the snake. Part of the snake was already inside the hole. But after this 'human' action of the narrator, the snake's reaction was different. It moved away hastily. Its movement is compared to a sudden, quick flash of lightning.

For he seemed to me again like a king, like a king in exile...

The poet has already confessed his respect for the snake by comparing it with God. But after hitting the snake with a stick and making it disappear in a foolish moment, once more the narrator compares it with a king, someone honorable and to be respected. The word 'again' expresses how his attitude keeps changing.

Besides similes, we come across other poetic devices in the poem that prove the power of poetic language. They are as follows:

A wonderful example of transferred epithet is observed in the following line:

Proceeded to draw his slow length...

The snake's speed was slow and not its length. By saying slow 'length' the poet has succeeded in saying that it took a very long time for the snake to move away, because it moved very slowly.

The poem also contains an allusion.

And I thought of the albatross

And I wished he would come back, my snake.

It is an allusion to the albatross in S.T. Coleridge's poem, 'The Ancient Mariner'. It is most natural for the narrator to be reminded of the albatross because the circumstances are almost similar. After the snake goes away, he wishes that it would come back. This time, he refers to it as 'my snake'. Indirectly, the snake is compared to the albatross, which is also a metaphor.

\section{LEXICO-SYNTACTIC LEVEL:}

This includes unusual or inverted word order, omission of words and repetition, piling of usual collocates, unusual collocates, archaic words, particular parts of speech, etc. a number of interesting examples are there in the poem.

And slowly turned his head, And slowly, very slowly, proceeded to draw its slow length

Repetition of the word 'slowly' emphasizes the slow speed with which the snake moved, indicating some kind of royal poise, a stately and majestic movement.

And truly I was afraid, I was most afraid...

The repetition of the word 'afraid' brings out the fear in the poet's mind.

For in Sicily, the black black snakes are innocent...

In this line we find an example of epizeuxis, that is, the repetition of the same word without any break at all. It is used to maintain a permanent effect on the reader/hearer and also for emphasis. Use of epizeuxis is so apt in this example 
because it is permanently imposed upon the human mind by education that in Sicily, the black snakes are innocent.

A similar example of epizeuxis is also found in the following line:

On a hot, hot day...

A number of sentences in the poem run into the next line. They are very long. They are compound sentences joined by the coordinating conjunction 'and'. The following lines begin with 'and':

- And must wait...

- And trailed his yellow-brown slackness...

- And rested his throat...

- And where the water had ...

- And I, like a ...

In all there are 22 lines in the poem that begin with 'and', few examples of which are given above. They are all continuation of previous lines. This makes the lines longer in length. The long lines seem to resemble the length of the snake. All the lines are related to the snake or its actions, hence, the poet achieves parallelism through the use of a large number of coordinating clauses.

There are only 4 lines in the form of questions. All lines that describe the snake are statements. The natural reaction of an individual, an educated and brave man is to kill the snake. But wherever the poet describes his unusual reaction to the appearance of the snake at his water-trough, he has posed questions.

- Was it cowardice that I did not kill him?

- Was it perversity that I wanted to talk to him?

- Was it humility to feel so honored?

Not killing the snake, wanting to talk to it and feeling honored by its visit are unusual, unexpected reactions. He is not sure whether they are right or wrong. The change in the structure from statement to interrogative indicates the change in his attitude. The question form also reflects the narrator's uncertainty about his own reactions. He wonders whether it is cowardice, perversity or humility on his part. By using 4 questions to interrupt the smooth flow of long sentences in statement form, foregrounding effect is created by the poet.

\subsection{Conclusion}

Whether it is fear, or feeling honored, or wanting to speak to the snake, or wishing to kill it, or regretting hitting the snake, on the whole, there is honesty in what the poet admits. His narration is actually 'loud thinking' because there is no one else present and he is not addressing anyone in particular. Hence, changing thoughts and reactions can be traced throughout the poem through the narration, which invariably reminds us of Browning's Dramatic Monologues. Since the focus is partly on the mind like a 'stream of consciousness' technique, what he expresses is true and honest. This is also evident in the confessional 
tone in the poem. The poem creates a strong impact and goes directly to the heart on account of this honesty, this admitting of feelings without any reservations.

This analysis shows that we can use stylistics to uphold an interpretation of a poem and it can also highlight elements of a poem that we might otherwise miss. It enables us to speculate with more certainty why D. H. Lawrence chooses to use long lines, deviant punctuation and how he tries to resemble the physical features of a snake in the graphical arrangement of the lines.

\subsection{Suggestions and recommendations}

Stylistic analysis of poems in various courses, particularly ESL or EFL courses can increase the understanding and confidence of students who are non-native speakers of English. Studies can be carried out for instructing students how to carry out stylistic analysis systematically. 


\section{References}

Akyel, A. (1995). Stylistic Analysis of Poetry: A Perspective from an Initial Training Course in TEFL. TESL Canada Journal, 13(1), 63-73.

Barry, Peter. "Beginning Theory: An Introduction to Literary and Cultural Theory." Manchester University Press, Manchester, New York, 1995.

Fish, Stanley Eugene. Is There A Text In This Class?. Cambridge, Mass.:

Harvard University Press, 1980. Print.

Gómez-Jiménez, E. M. (2017). Unconventional patterns in the experimental poetry of E. E. Cummings: A stylistic approach to punctuation marks. Language and Literature, 26(3), 191-212.

Wales, Katie. "A Dictionary of Stylistics." Routledge,1990, New York.

Widdowson, H. G, Guy Cook, and Barbara Seidlhofer. Principle \& Practice In Applied Linguistics. Oxford: Oxford University Press, 1995. Print.

Widdowson, H. G. Stylistics And The Teaching Of Literature. London: Longman, 1975. Print. 